\title{
Development of a methodology for measuring the evolution of duplex stainless-steel low-temperature plasma nitrided phases expansion using confocal laser scanning microscopy
}

\section{Desenvolvimento de uma metodologia para medição da evolução da expansão de fases nitretadas por plasma a baixa-temperatura de aço inoxidável duplex usando-se Microscopia Confocal de Varredura a Laser}

Carlos Eduardo Alves Feitosa ${ }^{1, *}$ (D), Rodrigo Perito Cardoso ${ }^{1}$ (D), Silvio Francisco Brunatto ${ }^{1,2}$ (D)

1. Universidade Federal do Paraná - Programa de Pós-Graduação em Engenharia Mecânica - Grupo de Tecnologia de Fabricação Assistida por Plasma e Metalurgia do Pó - Curitiba (PR), Brazil.

2. Universidade Federal do Paraná - Departamento de Engenharia Mecânica - Curitiba (PR), Brazil.

Correspondence author: carlos.feitosa@ufpr.br

Section Editor: Maria Lúcia P Silva

Received: Nov. 30, 2020 Approved: Feb. 02, 2021

\begin{abstract}
Samples of duplex stainless steel SAF 2507 were low-temperature plasma nitrided to characterize separately, on the surface, the behavior of its ferrite and austenite phases in relation to two competing processes, that is, one caused by enrichment by nitrogen, resulting in possible expansion, and the other caused by the removal of superficial atoms via sputtering, which may lead to the retraction of the studied phases. Since these phases have different different compositions and crystalline structures, of which the diffusivity and solubility of nitrogen in them are dependent, a different response for each type of phase can be expected. In this article, an innovative methodology has been developed to quantify and clarify which effects are predominant in the course of nitriding for each of these phases. The results indicate that phase expansion prevails over sputtering.
\end{abstract}

KEYWORDS: Plasma nitriding, SAF 2507 duplex stainless steel, Nitrogen-expanded phases, Sputtering.

\begin{abstract}
RESUMO
Amostras de aço inoxidável duplex SAF 2507 foram nitretadas por plasma a baixa-temperatura visando caracterizar, separadamente, na superfície, o comportamento de suas fases ferrita e austenita em relação à dois fenômenos competitivos, no caso, um causado pelo enriquecimento de nitrogênio, resultando em possível expansão e, outro, causado pela remoção de átomos da superfície por meio de pulverização catódica, o qual pode levar à retração das fases estudadas. Uma vez que essas fases têm composição e estrutura cristalina diferentes, das quais a difusividade e a solubilidade do nitrogênio nelas são dependentes, uma resposta diferente para cada tipo de fase pode ser esperada. Neste artigo, uma metodologia inovadora foi desenvolvida para quantificar e esclarecer quais efeitos são predominantes no curso da nitretação para cada uma dessas fases. Os resultados indicam que a expansão de fase prevalece sobre a pulverização catódica.
\end{abstract}

PALAVRAS-CHAVE: Nitretação por plasma, Aço inoxidável duplex SAF 2507, Fases expandidas por nitrogênio, Pulverização catódica. 


\section{INTRODUCTION}

Low-temperature plasma nitriding is a technology used for modifying the properties of stainless-steel surfaces, usually resulting in an increase of both hardness ${ }^{1}$ and corrosion resistance ${ }^{2}$ without necessarily modifying these properties in the substrate bulk. Low-temperature plasma nitriding technology is applied to stainless steels aiming to avoid that the chromium solved in the matrix solid solution leaves this condition to form stable nitride precipitates. It has been seen in the literature that such phases are deleterious ${ }^{3}$, and they appear under very specific conditions, such as high temperature or high exposure time to relatively low temperatures ${ }^{4}$. However, in the technical-scientific literature two competing factors, influencing the surface topology modification, take place during plasma nitriding: the sputtering 5 , and the matrix phases expansion by the action of nitrogen ${ }^{6}$.

Sputtering is the ejection of atoms into the glow region by the high-energy ions' bombardment. Then, it is expected that, due to this effect, the surface of the samples exposed to the plasma tends to be eroded along nitriding, similar to the verified from a wear effect. On the other hand, the expansion of phases by the surface enrichment from nitrogen atoms is expected to occur by increasing the lattice parameter, thus implying in the elevation of the sample surface.

Some recently published works have shown the growth of the nitrided layer as a function of the nitriding temperature or time ${ }^{7-9}$, but the quantitative techniques available to measure such a layer are almost always destructive. It is worth mentioning that, at least from the authors' knowledge, no study has been developed up to the moment aiming to characterize if the real nitrided layer evolution leads the sample geometry to be swelled (as a result of the net layer growth to the plasma direction), or, differently, to be shrunk (as a result of the net layer growth into the substrate bulk).

In the specific case of duplex stainless steel, which presents ferrite and austenite phase balanced microstructure, one has the advantage of studying the action of nitriding on both phases simultaneously. However, due to the lack of an efficient and reliable method of measuring the sample height, before and after nitriding, reports available in the literature are mostly qualitative. Thus, a methodology was developed to follow grains before and after nitriding, as well as to monitor the height of the nitride phases to clearly determine which of these effects prevails, in net way, in the present treatment. The main characteristic of this method is that it is non-invasive, but also quantitative.

\section{EXPERIMENTAL}

Duplex stainless-steel $20 \times 20 \times 3 \mathrm{~mm}^{3}$ samples presenting chemical composition of Fe-25.5Cr-6.6Ni- $4.1 \mathrm{Mo}$, in wt.\%, were ground with sandpaper and polished to $0.020 \pm 0.004 \mu \mathrm{m}$ Sa roughness. Vickers indentation marks were then made on the polished surface to make easier to locate the grains under the confocal laser scanning microscope (CLSM) observation. For this purpose, an Olympus OLS4100® equipment was used. One indentation of $1 \mathrm{~kg}$ load was made in the center of the sample to make ease the marks location afterwards, by using an optical microscope.

The whole procedure was constituted of making eight other smaller indentations (with $0.1 \mathrm{~kg} \mathrm{load}$ ), arranged in three different squares from which the vertices were separated $500 \mu \mathrm{m}$ one each other, as shown schematically in Fig. 1.

In the sequence, a stainless-steel plate of $\approx 100 \mu \mathrm{m}$ thickness was welded to a region of the polished surface in such a way to prevent the area below it to be thermochemically treated. This procedure was necessary to determine a zero-level reference for the height measurements to be carried out after the nitriding treatment. The plate was welded by the point welding process, in which a 10,000 $\mathrm{FF}$ electrolytic capacitor was charged with a $20 \mathrm{~V}$ power supply, being discharged into the stainless-steel plate already positioned to partially cover the indentation marks, as shown in the schematic Fig. 2.

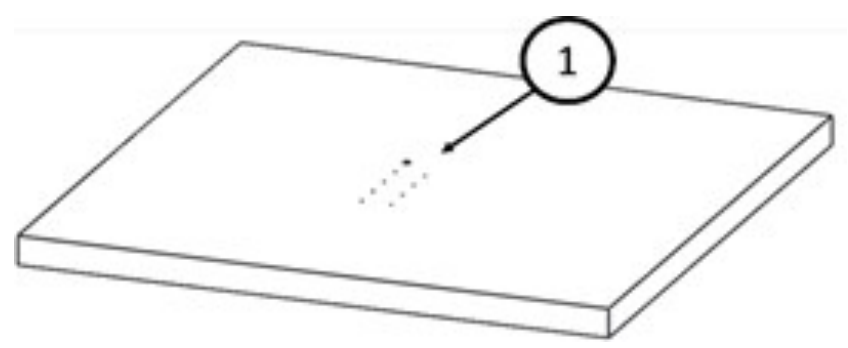

Figure 1: Schematic of the duplex stainless-steel sample with Vickers indentations on the polished surfaces ${ }^{6}$. 


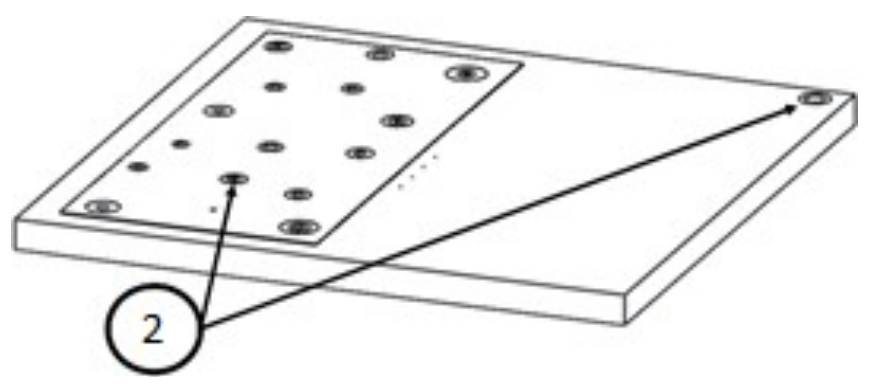

Figure 2: Schematic showing the spot welding of the stainless-steel blade on the sample surface to partially cover the Vickers indentations ${ }^{6}$.

The plasma nitriding process was carried out in a glow discharge chamber using 70\% N2, 10\% Ar and $20 \% \mathrm{H} 2$ gas mixture, and a $700 \mathrm{~V}$ pulsed power supply, being the temperature was controlled by the pulse switched-on time. The pressure was 3 Torr $(400 \mathrm{~Pa})$. Details of the chamber configuration can be seen in Feitosa ${ }^{6}$. The treatment temperature was maintained at $350^{\circ} \mathrm{C}$ for 9 hours.

Before plasma nitriding in the glow discharge chamber, each sample was cleaned by immersion in an ethyl alcohol bath and cleaned in an ultrasonic bath for 10 minutes. Then, a heated airflow was used to accelerate the evaporation of alcohol. The plasma cleaning standard procedure adopted in the Laboratório de Pó e Tecnologia de Plasma of the Universidade Federal de Paraná consisted of a heating up to $300^{\circ} \mathrm{C}$, under $20 \% \mathrm{Ar}+80 \% \mathrm{H} 2$ plasma, and keeping this condition for $30 \mathrm{~min}$. After plasma cleaning, the sample was heated up to the treatment temperature, and so the N2 was introduced in the gas mixture. Once the nitriding was finished, the electric power supply was turned off to immediately stopping the plasma. The sample was left in the reactor under the nitriding gas mixture flow until room temperature was reached, when the chamber was opened and the sample removed.

An image stitching procedure was used to capture and assemble sequential images aiming to determine in a same image pattern, scanned from a treated region up to an untreated region, all distinct analyzed regions, keeping unaltered a same reference height for all captured images. As a whole, four $635 \times 635 \mu^{2}$ image patterns, achieved in the CLSM using 200 times magnification, wereused to characterizeeach nitrided surface.

Won all these steps, the sample (analysis surface) slope was firstly corrected by applying a parallelism geometric tolerance between the top and the lowest face of the untreated sample. After that, with the sample already treated, the treatment mask was removed, then the residual slope was resolved using the height of two distinct regions on the nitrided surface, as observed in Fig. 3A, over $500 \mu \mathrm{m}$ from the treated to untreated region. For all studied cases, edge effect regions at the plasma nitrided samples were always avoided. Regions indicated with 1 and 2 were used to correct the inclination along the vertical axis, while regions 3 and 4 for the correction along the horizontal axis. The simple height with no correction can be seen in Fig. 3B. With the obtained values for this simple height and the distance between the centers of these two regions, the slope correction was easily estimated using the arctangent trigonometry function, by inserting these values in the microscope software. Finally, as a successful result, Fig. 3C shows the corrected sample surface view, which now was ready to be used for the ferrite (a)- and austenite (y)-grains' height measurement characterization, with a very good precision.

With this methodology, it was also possible to adopt two standardized measurement procedures regarding the untreated region of the image. The first one was termed here as the overall height of the sample, and concerns the height of the sample taking into account a wide treated region away from the edge effect region. In this case, an average height of the sample was measured, regardless of the two different ( $a$ and y) phases present. The second procedure aimed to determine the local height of each phase, separately. In this second approach, a specific very small square area was used to measure individually each grain height, so all its edges fit inside the measuring grain. Thus, by collecting the relative height of several ferritic and austenitic grains, it was possible to describe which of these phases had the largest perpendicular growth when referred to the sample surface, and, additionally, if the height variation was positive (to the outside of the surface) or negative (to the inside of the surface). 

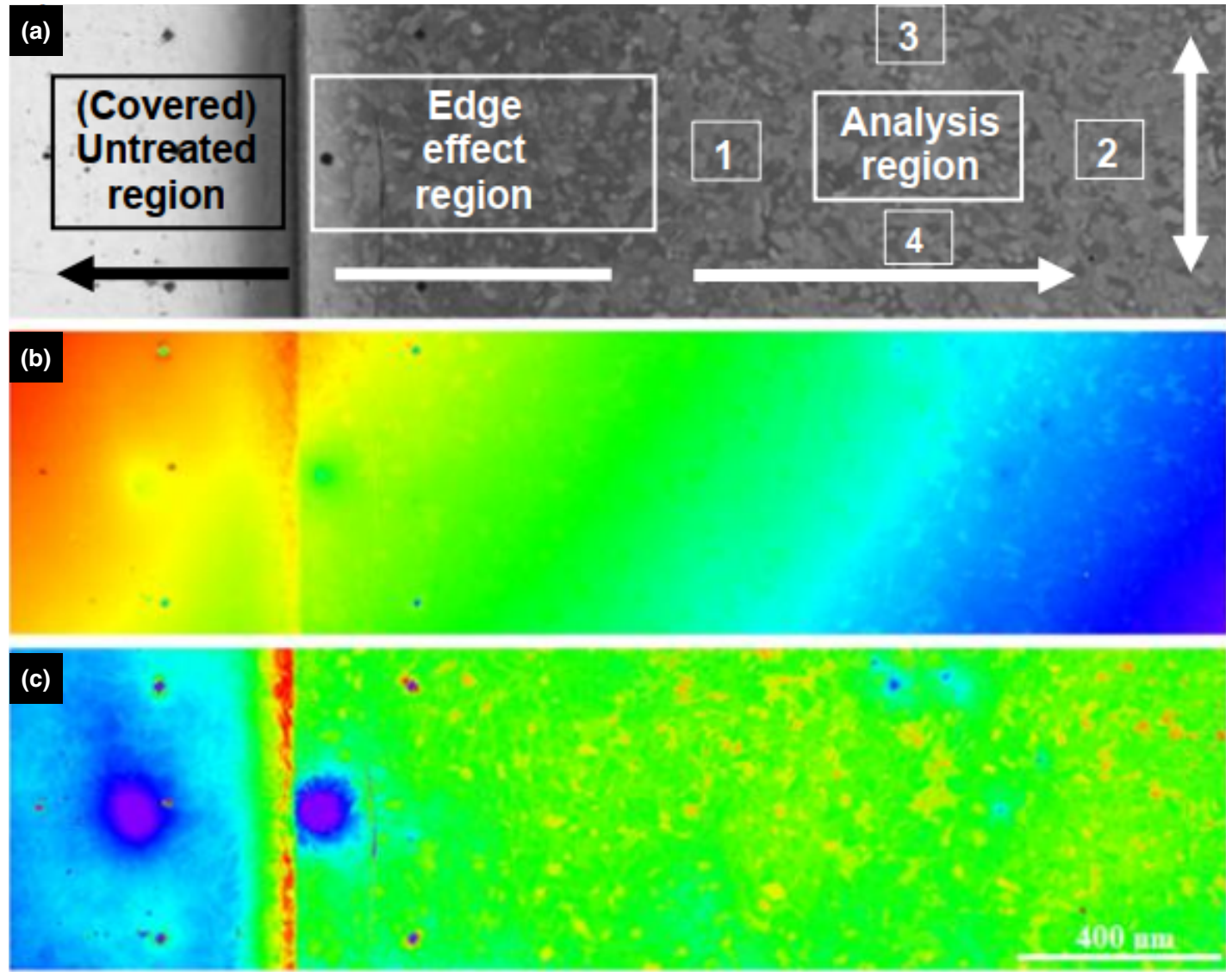

Figure 3: Method used for height measurement via confocal laser scanning microscope (adapted from Feitosa ${ }^{6}$ : (a) view of the treated surface, with the indication of the nitrided region, the border (due to the previously welded plate) effect region and the analyzed region; (b) the obtained sample image pattern with residual slope;

(c) the sample image pattern with the corrected slope and ready for analysis.

\section{RESULTS AND DISCUSSION}

Figure 4 shows result in which it is possible to clearly visualize the viability of this new measurement methodology presented here. On the left side of Fig. 4, it can be seen the region that was covered by the welded stainless-steel plate, as well as four of the eight 0,1 kg indentation marks (indicated by white arrows). On the right side, it can be seen the region that was effectively nitrided. In this condition, the sample surface's average height was increased by $209 \mathrm{~nm}$ compared to the untreated region. To reach this value, an area of $400 \times 400 \mu \mathrm{m}^{2}$ was used, for the two green square areas represented in Fig. 4.

Specifically for the conditions presented here, it was evidenced that the effect of the expansion of phases prevails over sputtering, which means that the region of the treated sample is higher than the untreated region. Another way to qualitatively observe this result is by the green line profile at the top of the image, which reveals a shoulder on the untreated (with smaller height) $\times$ treated region (with higher height) interface, remaining higher up to the center of the green square at the right side of the image.

In the detail of Fig. 4, it is also possible to see how the local heights on the different ferrite (a)- and austenite (y)-grains were measured with the chosen magnification. It was noticed that the rectangle used to measure the phase height was reduced in order to as to remain whole within the limits of the grain boundaries. Altogether, 30 samples of local height were used for each phase, evaluated at $162.5 \pm 17.5 \mu \mathrm{m}$ for austenite and $180 \pm 17.9 \mu \mathrm{m}$ for ferrite.

This method allowed to study the evolution of the growth of nitrogen-enriched phases in duplex stainless steels in terms of the sample surface, adding to the conventional analysis techniques. These phases' evolution is a function of nitriding temperature, and time will be published in future work. 


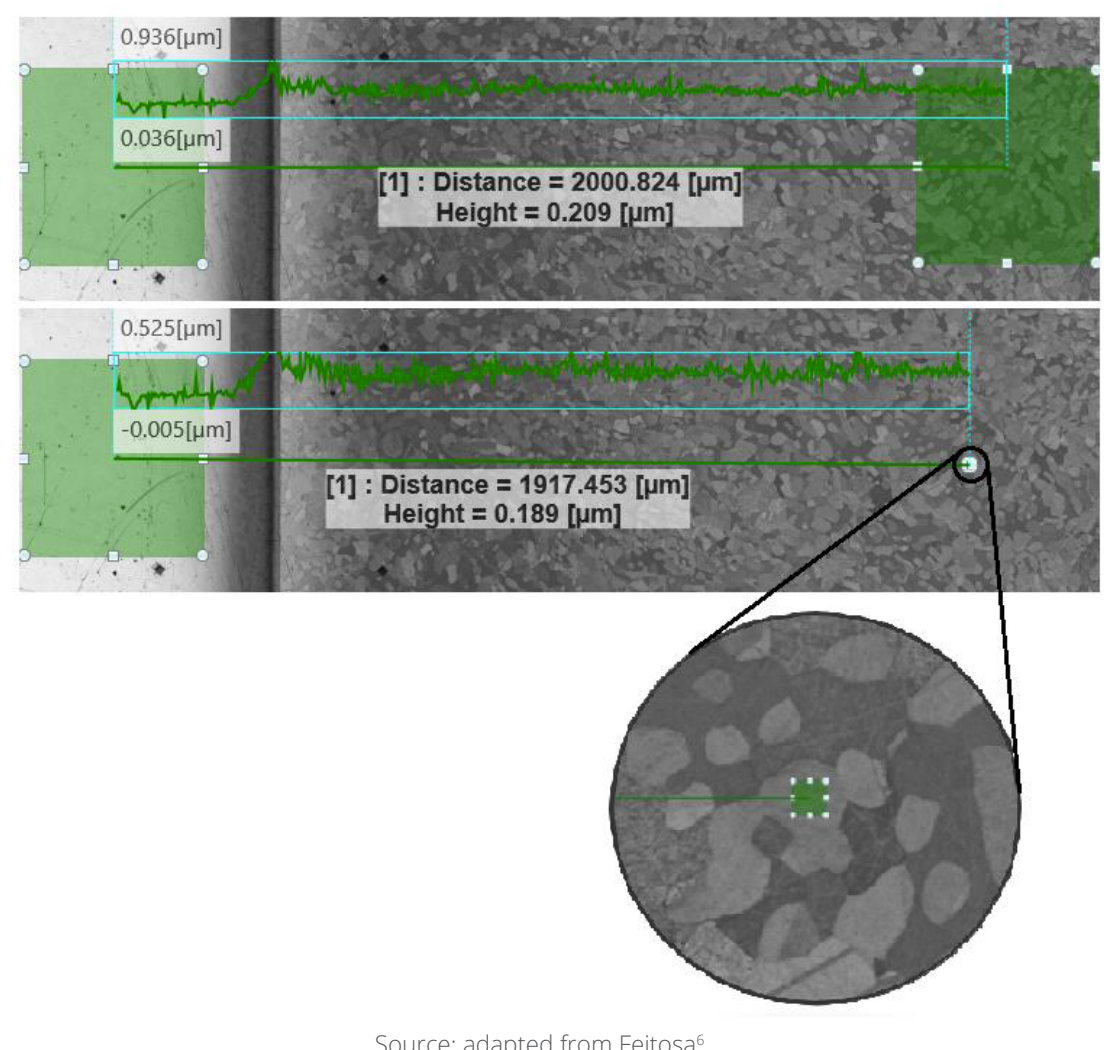

Figure 4: Method used for height measurement via confocal laser scanning microscope.

\section{CONCLUSIONS}

Based on what has been presented, the following conclusions can be drawn:

- The developed method to quantify the sample height was a success;

- For the presented low-temperature nitriding condition, both the austenitic and ferritic phases had an increase in volume, indicating that the expansion of phases prevails over sputtering.

\section{AUTHORS' CONTRIBUTIONS}

Conceptualization: Brunatto SF; Funding Acquisition: Brunatto SF, Cardoso RP; Project Administration: Brunatto SF; Supervision: Brunatto SF; Validation: Brunatto SF, Cardoso RP; Writing - Review \& Editing: Brunatto SF; Formal Analysis: Cardoso RP; Resources: Cardoso RP; Data Curation: Feitosa CEA; Investigation: Feitosa CEA; Methodology: Feitosa CEA; Visualization: Feitosa CEA; Writing - Original Draft: Feitosa CEA.

\section{DATA AVAILABILITY STATEMENT}

All dataset were generated or analyzed in the current study.

\section{FUNDING}


Conselho Nacional de Desenvolvimento Científico e Tecnológico

https://doi.org/10.13039/501100003593

Grant no. 482380/2012-8

Ministério da Ciência, Tecnologia e Inovações

https://doi.org/10.13039/501100003545

Grant no. 456347/2013-5

Fundação Araucária do Estado do Paraná

https://dx.doi.org/10.13039/501100004612

Grant no. 46744

\section{ACKNOWLEDGEMENT}

To Laboratório de Materiais e Tratamentos Superficiais of the Universidade Federal do Paraná, for the use of the confocal laser scanning microscope.

\section{REFERENCES}

1. Pinedo CE, Varela LB, Tschiptschin AP. Low-temperature plasma nitriding of AISI F51 duplex stainless stell. Surf Coat Tech. 2013;232:839-43. https://doi.org/10.1016/j.surfcoat.2013.06.109

2. Li Y, Zhang S, He Y, Zhang L, Wang L. Characteristics of the nitrided layer formed on AISI 304 austenitic stainless steel by high temperature nitriding assisted hollow cathode discharge. Mat Design. 2004;64:527-34. http:// dx.doi.org/10.1016\%2Fj.matdes.2014.08.023

3. Lipold JC, Kotecki DJ. Welding metallurgy and weldability of stainless steels. United States: John Wiley e Sons; 2005.

4. Nilsson JO, Wilson A. Influence of isothermal phase transformations on toughness and pitting corrosion of super duplex stainless steel SAF2507. Mat Sci Technology. 1993;9(7):545-54. https://doi.org/10.1179/mst.1993.9.7.545

5. Chapman BN. Glow Dischange Process. United States: John Wiley \& Sons; 1980.

6. Feitosa CEA. Evolução da camada nitretada a baixa temperatura sobre as fases a e y do aço inoxidável duplex SAF 2507: estudo a partir de uma técnica de rastreamento de grãos [dissertation]. Curitiba: Universidade Federal do Paraná; 2020.

7. Czerwiec T, Andrieux A, Marcos G, Michel H, Bauer Ph. Is "expanded austenite" really a solid solution? Mössbauer observation of an annealed AISI 316L nitrided sample. J Alloys Compd. 2019;811:151972. https:// doi.org/10.1016/j.jallcom.2019.151972

8. Braceras I, Ibáñez I, Dominguez-Meister S, Sánchez-García JA, Brizuela M, Larrañaga A, et al. Plasma nitriding of the inner surface of stainless steel tubes. Surf Coat Technol. 2017;355:116-22. https://doi.org/10.1016/j. surfcoat.2018.04.057

9. Lima J. Caracterização microestrutural, mecânica e tribológicas do aço inoxidável super duplex Saf 2507 (UNS S32750) nitretado por plasma a baixa temperatura [dissertation]. Curitiba: Universidade Federal do Paraná; 2019. 